\title{
LEAN MANAGEMENT AS AN INSTRUMENT OF SUSTAINABLE DEVELOPMENT OF ENTERPRISES
}

\author{
Maciej KWIATKOWSKI, Karolina LORENC, Daria NOWICKA, \\ Hanna PROSÓt, Marcin SIKORA \\ University of Zielona Góra \\ Laurena PHAM \\ Azusa Pacific Univercity
}

\begin{abstract}
:
The aim of the paper is to present the philosophy of Lean Management as an instrument of improving sustainable management of enterprises. The article presents the origins, characteristics of the broadly understood concept of Lean Management and describes the idea of Sustainable Development (SD). At the same time implications for the application and development of the instruments which operationalize the assumptions of SD at the level of enterprises are discussed. The paper specifies those areas of functioning of contemporary companies in which Lean Management can be implemented and compares them with the features of traditional management in particular subjects
\end{abstract}

Key words: Lean Management, Sustainable Development, integrated enterprise management systems

\section{INTRODUCTION}

With the increasingly growing expectations of customers in respect of product quality, flexibility of production and supply, entrepreneurs have take into accounts ecological aspects of production and administrative processes. Lean Management (LM) is one of the instrument of sustainable development which supports the dynamic revolution of the company in the direction which agrees with such expectations.

Thanks to corporations such as Toyota Motors Company specific tools used in Lean management were developed. On the basis of the practice of the above mentioned company, other enterprises implement the Lean concept in their day to day practice of their functioning. The brand Oriflame, which at the break of 2007 and 2008 introduced changes in management based on LM can be used as an example. The use of the methods stabilized production and influenced positively the image of the company among customers. In order to show haw changes in the organization of an enterprise based on the idea of LM and sustainable development influence the development of the company, the paper discusses the issue of "lean management".

\section{THE ORIGINS OF LEAN MANAGEMENT}

Lean Management consists in its essence consists in efficient use of resources, minimization of costs, use of appropriate processes and simultaneous offering of high quality service, products etc. in order to satisfy customers [19]. The philosophy was developed in Japan and for the first time implemented in economic practice by Kiichiro Toyoda, the founder of the Toyota Motor Company. At present increasing more manufacturers follow this style of management initiated in a Japanese enterprise. Their actions are motivated above all by offering products and services which meet the expectation of the customers in respect of quality, and simultaneous minimization of the costs of functioning [5].

The history of Toyota started in the $19^{\text {th }}$ century. Sakichi Toyoda, the father of Kiichiro, invented a mechanical loom, unknown previously in Japan. This let him start a company Toyoda Spinning \& Wearing Company in 1918. After six years his son constructed a workshop annd in 1926 Toyota Automatic Loom Works was founded. Kiichoro Toyoda travelled in Europe and the United States and had an opportunity to the arising motor industry branch in 1920s. He sold the patent rights to the loom, and invested the money in a motor company. In this way Toyota Motor Company (TMC) was founded in 1937 [13].

Kiichiro i SakichiToyoda applied the principles of ",just-in -time" and "Jidoka". The "just-in-time" consisted in the production of such volumes of products for which there was a demand. This allowed to use the resources effectively and maintain high quality of products. "Jidoka" means production of such volumes of products for which there is a demand. In this way the Toyota Production System was developed, which became the basis of Lean Management [16].

The Toyota company also implement the system of Kaizen that is the need for "constant improvement". 10 basic principles of Kaizen can be distinguished:

1. Throw out all your old fixed ideas on how to do things.

2. No blame - treat others as you want to treated.

3. Think positive - don't say can't.

4. Don't wait for perfection $50 \%$ improvement now is fine.

5. Correct mistakes as soon as they are found. 
6. Don't substitute Money for thinking - creativity before capital.

7. Keep asking why until you get to the root cause.

8. Better the wisdom of 5 people that the expertise of 1.

9. Base decisions on data not opinions.

10. Improvement is not made from a conference room.

In LM, Kaizen allows to increase the involvement of all employees and increase the improvement of the processes and resources used. For this purpose various forms of motivation are used in the form of rewards. According to this principle changes should be introduced gradually. Big and rapid changes may not be accepted by the staff, which in turn may lead to the collapse of the entire system [6].

The policy of Sikachi and Kiichiro Toyodo was continued by Teiich iOhno. He introduced a new concept into the Toyota Production System, which is muda i.e wastage. Various types can by distinguished. One of them waiting since at that time the value of the product does not increase. There are many manifestations of wastage e.g. unnecessary transport, actions or transfer of resources. Also overproduction, defects, excessive reserves are against the principles of TPS. Additionally wastage can take the form of excessive processing of reserves which does increase the value of the product. Ohno aimed at maximum reduction or complete elimination of all types of muda [9].

Lean Management Carnot be applied only in production processes (Lean Manufactring) in the company The approach must be holistic and hence apply to the entire company. Thus, with time such concepts as Lean Accounting or Lean Office were introduced.

Toyota Motor Company succeed by introducing techniques of Lean Management. Until the end of the $20^{\text {th }}$ century the company sold 100 million cars in Japan. Yet it did not limit itself to the Japanese market. In 1957 various models of Toyota reaches the United States in in $1963 \mathrm{Eu}$ rope. At present TMC has 28 branches and 3000 selling points on 5 continents [11].

\section{THE ORIGINS OF THE CONCEPT OF SUSTAINABLE DEVELOPMENT}

The problem of "sustainable development" as a significant element of public discourse appeared for the first time on the international forum in result of the publication by so called Club of Rome of the report "The limits of growth" in 1972. The very definition of sustainable development was formulated in the Report of the World Committee for Environment and Development, so called Brundtland Report in 1987. Generally accepted definition has the following wording "Development meeting the requirements of present times which does not limit the capability of future generation in respect of satisfying their needs" The definition was detailed in document of UN, in which "sustainable development" is "development which satisfies the basic needs of all people, preserves, protects and recovers the health and integrity of the eco-system of the Earth, does not threaten the possibility of satisfying the needs of future generations, and does not cross the long-term limits of the capacity of the eco-system of the Earth' The definition includes the en tire scope of relations between the economic sphere of human acticity, limited resources of the environment, which constitute a natural limit of the possibility to satisfy needs, and the ethical imperative of assuring social cohesion. The essence of sustainable development consists in the fact that while evaluating undertaken actions, their impact on the social and natural environment in the long term perspective must be taken into account. Thanks to the strategy of economic growth, whose aim is not only to increase the production and consumption of goods, but also the improvement of the quality of life, it is also possible to achieve the aim which requires implementation of actions related simultaneously to three areas:

- the economic sphere - by maintaining a long term economic growth covering all countries and societies, including the ecological perspective,

- the ecological sphere - by the protection of natural resources and the environment for future generation, implementation of economically national solution reducing the consumption of natural resources,

- the social sphere - by assuring possibly widest access to employment, food, education, energy, health care, water and sewage system [17].

The concept of sustainable development appeared as an attempt to respond to a set of threat which in 1960s were perceived in forecasted high demographic growth, rapid consumption of natural resources, increasing pollution of the environment, failure to satisfy the basic needs of increasingly larger groups of people and significant destabilization of natural, social and economic systems. The increasing concern with the situation and widespread exploitation of natural resources, uncontrolled, regional demographic and urban development processes as well potential disruption in the future economic development at the global scale, created the need to develop a global strategy preventing such threats [17].

The Business Carter of Sustainable Environment constituted a significant point in the evolution of the concept of sustainable development. The background literature indicates that it was the result of increasing number and intensity of social appeals concerning environment protection, to which the industry responded in 1992. The biggest world concerns signed so called "ICC Business Charter for Sustainable Development". The signatories of the Charter accepted 16 principles of ecological management as directives for business activity. The first of the principles specifies directives related to ecology: "Environment management should be one of the most important priorities of corporations as a key factor leading to the achievement of sustainable development; there is a need to develop policy programs and practice of actions in a way which is beneficial for the environment".

During the Stockholm Conference, in which 113 countries participated, a declaration consisting of 26 points and concerning directly the problem of degradation of the environment as well as means of preventing the threat, was accepted. The Stockholm Declaration form the basis for the future development of law on environment protection. Specific issues were recapitulated and this gave an impulse to the initiatives undertaken in view of sustainable development. The Stockholm declaration remains relevant since it raises the basic questions concerning environment protection:

- the right to appropriate life conditions in the environment,

- responsibility for protection and improvement of the environment for prezent and future generations,

- responsibility of people for the natural heritage,

- prevention of the pollution of eco-systems,

- ecological policy [15]. 
In result of disturbing report on the conditions of the natural environment "Environment and development", in 1992 a UN Conference was held. The superior aim of the conference was to "define new and just global partnership be creating new levels of cooperation between the countries, key groups of associations and people working to the benefit of international agreements which reflect the interest of all people and protect the integrity of global environment and development systems, considering the integral and co-dependent character of the Earth, our home".

The conference in Rio de Janeiro was a breakthrough and initiated so called "Ecological era" whose effect was the announcement of 27 principles of "The Rio Declaration" and approval of the so called Agenda 21 (Global Program of Actions) by 178 governments. The document presents the agreed position of the parties, whose aim is to change the current policy in the direction of a system which would support the solution of social, economic and environmental problems at the global level [2].

Thirty years after the Stockholm conference and 10 years after the conference in Rio de Janeiro, the third UN ecological conference was held in Johannesburg (RSA) under the heading of sustainable development of our planet.

Many documents and directives approved at the conference present ambitious goals to be achieved in the years 2010-2020, such as a significant reduction of people starving, living for less than one dollar per day or living in slums, improving the sanitary status of neglected environments ad supplying them with water, improving access to the sources of energy, in particular renewable energy, reduction of threats to human life and health in result of excessive and harmful chemicalization, improvement of purity of air, protection of the ozone zone etc.

The Basic problem discussed within the Framework of the concept of eco-development, and consequently sustainable development covered two related issues:

- detrimental impact of the economic activity on the natural environment,

- social and economic consequences of the degradation of the environment [20].

\section{DEVELOPMENT OF THE INSTRUMENTS OF SUSTAINABLE DEVELOPMENT IN COMPANIES}

In 1993 the resolution of the European Economic Community - European Union no. 1836/93 "on free participation of production companies in the Community ecomanagement and audit scheme" so called EMAS no. $1836 / 93$ was passed. The aim of EMAS is to encourage various organizations to improve their activity for the benefit of the environment by observing standards and regulations concerning environment protection and introduce relevant changes in the patterns of production and consumption for such which agree with the principles of sustainable development [18].

Furthermore in 1996 the ISO standard was published, which has been updated several times over the recent years, in which the requirements concerning the development of the environment management systems in various types of organizations were presented, irrelevant of their type, size, geographical, cultural or social conditions. The basic task of the ISO 14001 standard is to support actions related to environment protection as well as reduction and prevention of pollution, and the model presented aims at constant improvement. The current ISO 14001:2015 standard focuses on aims and leadership and at the same time limits the number of requirements which have imperative character. The ISO 14001 standard assumes the principles of the management system which agrees with the quality standards expressed in the ISO 9001:2015 standard, whose aim is to adapt the requirement of the standard to changing conditions in the dynamic world of business and at the same time create a user friendly standard [8].

In practice there are numerous instruments of sustainable development of enterprises. In the academic discourse the evolution of the instruments of sustainable development of companies can be observed since the second half of the $20^{\text {th }}$ century when the first methods and concept appeared. Table 1 presents the most important moments in the development of instruments of sustainable development of companies.

\section{LEAN MANAGEMENT AS AN INSTRUMENT OF OPERATIO- NALIZATION OF THE CONCEPT OF SD AT LEVEL OF ENTERPRISES}

The contemporary state of knowledge about management as well as Access to the descriptions of case studies from all over the world demonstrate that there are numerous concepts or methods of management which can guarantee success in the functioning of a particular enterprise. In practice managers resort to various solutions in order to assure competitiveness of companies. Lean management along with its tools offers such opportunity which can be used by the persons responsible for the development of companies [11].

While implementing Lean management it has to remembered that changes must apply to the e tire enterprise. Standards must reach all departments, offices and employees of the organization. "The essence of lean management consists in "leaning" an enterprises by introducing significant changes in the scope of its activity, in the structure of assets, in the form of organization and staff management as well as in shaping the behavior and attitudes of the employees" [14].

Thus it easy to observe that the principles of the Toyota Production System do not to apply to manufacturing companies only. This is confirmed by the practice of functioning of enterprises on both national and international markets, since after the success in the motor industry, Lean management becomes popular in logistics, insurance, banks, health care (Lean Healthcare) and even public administration (Lean Administration). It can be observed that the foundation of lean management remain stable and do not depend on the branch in which it is expected to be implemented [7]. Although in numerous academic papers lean management is identified with the elimination of wastage, which does not generate the added value, it has to be remembered that in practice this is much wider, multifaceted philosophy requiring changes in the culture of organization.

Table 2 presents significant features of company management according to traditional principles and the principles of Lean Management. The analysis allows for better understanding of this modern concept of management.

The concept of Lean Management combines various tools, which allows for the development of flexible organization, capable of reacting to forthcoming changes inside the organization and in its environment [4].

In practice, in view of its multifaceted nature, the approach applied also to the environmental activity of contemporary enterprises. 
Table 1

Evolution of instruments for sustainable development of the company

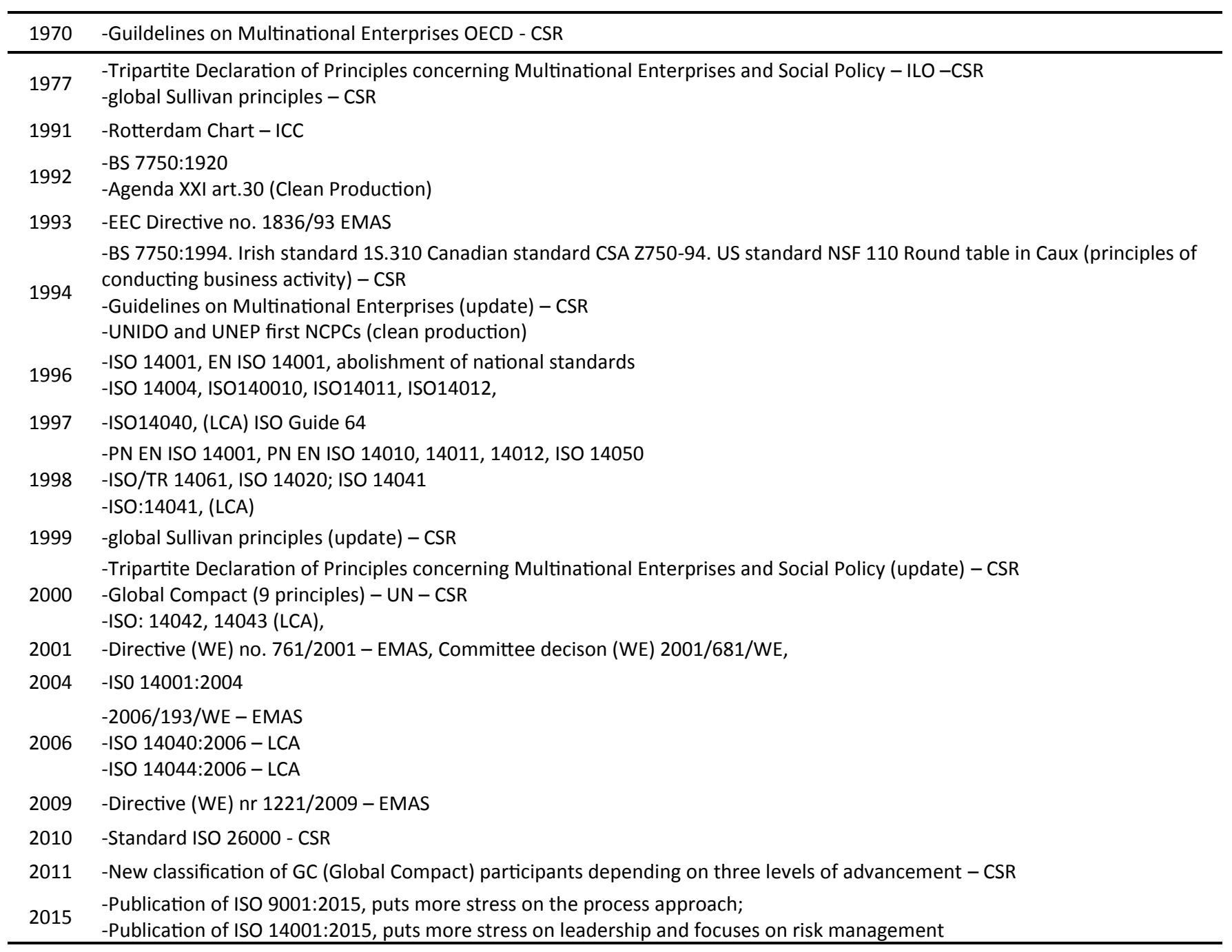

Source: on the basis of [10].

Table 2

Comparison of the two concepts of organization management

\begin{tabular}{|c|c|c|}
\hline Item & Traditional management & Lean management \\
\hline Integration of processes & Limited & Advanced / high \\
\hline Hierarchy of organization & Extended, formal and centralized & Flat structure, not formal or hierarchical \\
\hline The role of staff & Constant supervision & $\begin{array}{l}\text { Encouraging the role of staff, which constitutes } \\
\text { the relevant element of the organization; } \\
\text { continuous training }\end{array}$ \\
\hline Definition of the flow & Production of large bulks & Constant flow of products. \\
\hline Cooperation with suppliers & $\begin{array}{l}\text { Many accidental suppliers, enforcing } \\
\text { agreements }\end{array}$ & $\begin{array}{l}\text { Long term partner cooperation, limited } \\
\text { number of suppliers }\end{array}$ \\
\hline $\begin{array}{l}\text { The influence of the customer on the } \\
\text { process }\end{array}$ & $\begin{array}{l}\text { Limited impact on the products and } \\
\text { innovation }\end{array}$ & $\begin{array}{l}\text { Clients are partners in the process developing } \\
\text { innovation }\end{array}$ \\
\hline
\end{tabular}

Source: on the basis of $[7,10]$.

The principles of sustainable developments require limited use of natural resources and minimization of waste or emission of pollution. It is possible to observe convergence between Lean Management and sustainable development. "Both concepts require special care for resources (especially natural resources), that is rationalization of the use of space, matter and energy. Constant improvement expressed in Kaizen becomes synonymous with permanent sustainable development" [12]. In the countries in which the ecological awareness of purchasers is high, there are trends to shape a new, sustainable identity of organizations, achieved by means of implementation of new methods, techniques and tols which meet the legal requirements related to environment protection [3]. 


\section{LEAN MANAGEMENT AS FORM OF IMPROVING ORGANI- ZATIONS, THE CASE STUDYOF THE PRODUCTION OF COS- METICS IN ORIFLAME}

Oriflame was founded in Swede by two brothers and their friend in 1967. During 45 years it Has become and international cosmetics company offering direct sale in more than 60 countries and manufacturing their products in 6 factories in Sweden, Poland, Russia, India and 2 in China. Oriflame is listed in the stock exchange NASDAQ OMX.

1990s were the time of rapid development of the company, which brought success but also new challenges such as the crisis in Russia. Expansion led to changes in production - the factory in Dublin in Ireland was closed, and the production was moped to Poland and India. With the increase of the number of machines free space in production halls was reduced. With time, in view of limited space, trolleys for components were introduced, which limited the amount of reserves in the halls. This was an improvement relative to package delivery, yet the abandonment to optimize the entire stream of production did not affect the flexibility of the production process.

The dynamic development of the company in the first decade of the third millennium required growth in production capacity and higher efficiency in the internal chain of supply.

The decision to expand the factory in Warsaw in 2007 by additional production hall and a warehouse was motivated by the increase of the production potential by $25 \%$. At the same time the project of the reorganization of the global distribution network was initiated.

At that point the way of thinking about the form of improving efficiency changed. Oriflame Management decided to start the project of implementing Lean Manufacturing as a method of improving organization. The first Oriflame factory was selected in Poland. The efficiency of their own resources was far from satisfactory relative to the growth in sale. The expected level of customer satisfaction in result of limited flexibility of the factory was not reached. Despite involvement on the part of staff satisfactory result were not achieved. At the break of 2007 and 2008 there occurred a need to change the way of thinking. At the same time the pressure on factories grew and although new record were reached, the delay in delivery became an everyday norm.

Group Manufacturing in Oriflame intended to increase the efficiency of resources and increase the credibility of their factories as suppliers. Flexibility and cost efficiency resulted in the choice of Lean Manufacturing as a form of solving current problem and efficient use of the potential. Lean Manufacturing balanced the demand in the perspective covered by the strategy of the corporation with no need to increase the investment capital. Soon after the implementation, it occurred that the decision was right in view of the crisis. The benefits which Lean Manufacturing brought in other branches became even more significant and the determination among the management staff to achieve the goals supported the difficult period of the approval of changes.

The following mistakes were identified in internal situation of the company befor the introduction of Lean Management:

- lack of synergy in the flow between the lines of similar technology or categories of products,

- the capacity of the factory warehouse was too small for the necessary amount of components and Raw materials,
- traditional structure of the company, hindering simple implementation of new initiatives

- unstable schedule of delivery to the customers.

In practice the possibility for improvement depended on the increase in the availability of production materials and flexibility of production lines. In order to achieve that, TMP tools were implemented and stream improved by the staff were introduced, with the use visualization in the management of flow and standardization on the workstations (mapping and improvement).

\section{CONCLUSIONS}

Lean management as an instrument of sustainable development resulting the awareness of the real threat of depletion of natural resources, constitutes a way for improving the efficiency of production and simultaneous decrease of the costs of functioning of enterprises. The concept of 'lean' management the following factors are particularly important: advanced integration of processes, flat structure of organization reducing formalism, partner relations with suppliers based on long term contracts, empowerment of the staff which is a part of the company's structure and involvement of customers in actions related to production and introduction of innovations. Toyota Motors Company was the first enterprises which introduced Lean Management already in 1920s. The development of the principles of "Just-in-time", "Jidoka" or other tools used in production management enables constant development and a strong position of a company on the market. Undoubtedly, the introduction of good practice described in this paper offers a pattern not only for contemporary motor industry companies, but also firms from any other branches. That is why further popularization of Lean Management in other sectors may contribute, among others to the development of the entire economy in accordance with the paradigm of sustainable development, and in this way assure that the needs of present and future generations are satisfied.

\section{RENCERENCES:}

[1] P. Brewer, F. Kennedy, The Lean Enterprise and Traditional Accounting - Is the HoneymoonOver? "The Journal of Corporate Accounting \& Finance", September/ October2006.

[2] J. Ciechanowicz, Międzynarodowe Prawo Ochrony Środowiska, Wydawnictwo Prawnicze PWN, Warszawa 1999.

[3] A. Chmielarz,M. Wirkus - Środowiskowe aspekty wdrażania leanmanufacturing, w: Materiały konferencyjne: Innowacje w Zarządzaniu i Inżynierii Produkcji, Zakopane 2012, str. 169-176.

[4] J. Czerska: Usprawnianie przedsiębiorstwa produkcyjnego zgodnie z koncepcjq Lean, Zeszyty Naukowe Politechniki Gdańskiej, Gdańsk 2001, nr 588, str. 145.

[5] B. Gala, R. Wolniak, Problemy wdrożenia praktyk 5S w przedsiębiorstwie przemysłowym [w:] Management Systems in Production Engineering No 4(12), 2013.

[6] A. Hamrol, Strategie i praktyki prawnego działania lean, six sigma i inne, Wydawnictwo Naukowe PWN, Warszawa 2015.

[7] M. Hopiej, M. Szeloch: Lean Management - nowa koncepcja zarządzania, „Przegląd organizacji”, nr 2, 1994.

[8] A. Iwasiewicz, Zarządzanie jakością, Wydawnictwo Naukowe PWN, Warszawa 1999. 
[9] D. Jones, J. Womack, Lean thinking - szczupłe myślenie Eliminowanie marnotrawstwa i tworzenie wartości w przedsiębiorstwie, WordPress.com, Wrocław 2008.

[10] L. Kaźmierczak-Piwko, The development of instruments, Management Systems in Production Engineering No 4 (8), 2012.

[11] M. Krasiński Lean management w zapobieganiu i przezwyciężaniu kryzysu w przedsiębiorstwie. [Online]. Available: http://www.krasinski.ue.wroc.pl/

[12] Langas Group, Lean Management - Szerokim spojrzeniem dostrzeżesz nawet bardzo drobne element, [Online]. Available: http://polskiprzemysl.com.pl/

[13] O Toyocie. Wprowadzenie. [Online]. Available: http:// www.toyota.pl/

[14] J. Łuczak, ISO 9001. Skuteczny sposób uzyskania certyfikatu jakości, Wydawnictwo FORUM Sp. z o.o., Poznań 2006.

[15] J. Machowski, Ochronaśrodowiska. Prawo i zrównoważony rozwój, Wydawnictwo Akademickie „Żak” Teresa i Józef Śniecińscy, Warszawa 2003.
[16] J. Michalak J., Założenia, zasady I narzędzia leanaccounting (Zeszyty Teoretyczne Rachunkowości tom 49 (105)), Warszawa 2009

[17] T. Pakulska, M. Poniatowska-Jaksch, Rozwój zrównoważony - „szeroka i wq̨ska” interpretacja, stan wiedzy Szkoła Główna Handlowa.

[18] R. Paczuski, Prawo ochrony środowiska Unii Europejskiej w zarysie, Wyd. "Dom Organizatora", Toruń 1999.

[19] A. Piasecka-Głuszak, Poprawa innowacyjności i konkurencyjności polskich przedsiębiorstw przez zastosowanie koncepcji Lean Management (Zeszyty Naukowe Uniwersytetu Szczecińskiego nr 756 finanse, rynki finansowe, ubezpieczenia nr 57), 2013.

[20] G. Zabłocki, Rozwój zrównoważony. Idee, efekty, kontrowersje, Uniwersytet Mikołaja Kopernika, Toruń 2002.

Marcin Sikora, Maciej Kwiatkowski, Hanna Prosół,

Daria Nowicka, Karolina Lorenc

University of Zielona Góra

"Eco-Management" Student Research Club

ul. Podgórna 50 budynek A-0, 65-246 Zielona Góra, POLAND

e-mail: marcinsikora4@tlen.pl, maciek.kwiatkowski12@wp.pl, h.pr@wp.pl, darianowicka10@wp.pl,

karolinalorenc@outlook.com

Laurena Pham

Azusa Pacific University, USA

e-mail: Ipham12@apu.edu

Artykuł w polskiej wersji językowej dostępny na stronie internetowej czasopisma.
The article in Polish language version available on the website of the journal 